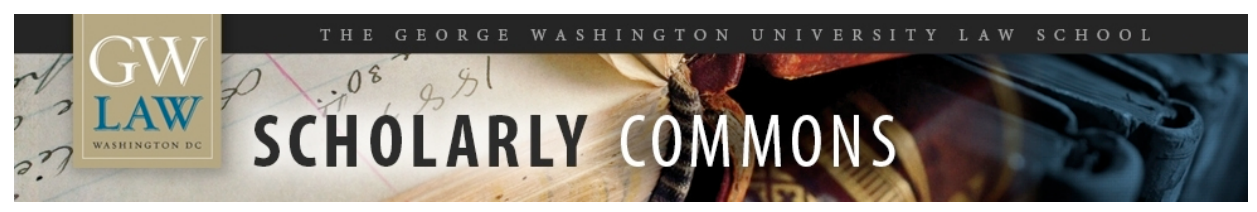

\title{
COMMERCIAL PRODUCTS AND SERVICES: Raising The Market Research Bar Or Much Ado About Nothing?
}

Steven L. Schooner

George Washington University Law School, sschooner@law.gwu.edu

Follow this and additional works at: https://scholarship.law.gwu.edu/faculty_publications

Part of the Law Commons

\section{Recommended Citation}

Schooner, Steven L., COMMERCIAL PRODUCTS AND SERVICES: Raising The Market Research Bar Or Much Ado About Nothing? (November 2018). 32 Nash \& Cibinic Report 92 (November 2018); GWU Law School Public Law Research Paper No. 2018-74; GWU Legal Studies Research Paper No. 2018-74. Available at SSRN: https://ssrn.com/abstract $=3276365$

This Article is brought to you for free and open access by the Faculty Scholarship at Scholarly Commons. It has been accepted for inclusion in GW Law Faculty Publications \& Other Works by an authorized administrator of Scholarly Commons. For more information, please contact spagel@law.gwu.edu. 


\section{THE NASH \& CIBINIC

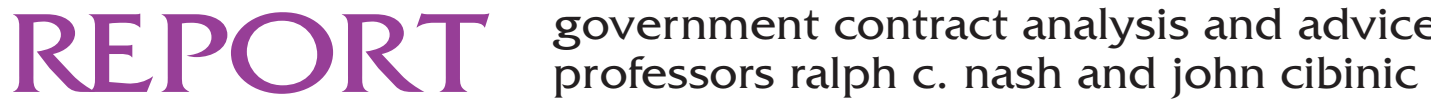

Author: Ralph C. Nash, Professor Emeritus of Law, The George Washington University Contributing Authors: Vernon J. Edwards and Steven L. Schooner

\section{ACQUISITION PLANNING}

\section{52 COMMERCIAL PRODUCTS AND SERVICES: Raising The Market Research Bar Or Much Ado About Nothing?}

\section{Steven L. Schooner}

Few predicted that Palantir USG, Inc. v. U.S., 904 F.3d 980 (Fed. Cir. 2018), 60 GC II 287, would be one of the year's most talked about cases. That perception is changing, as the decision appears to inject vitality and urgency into the longstanding requirement that, during acquisition planning, agencies must conduct market research to determine the availability of commercial solutions to their requirements. In Palantir, the U.S. Court of Appeals for the Federal Circuit affirmed the Court of Federal Claims decision (in Palantir's favor) that "the Army failed to determine whether commercial items meet or could be modified to meet the agency's needs and that, by failing to do so, the Army acted in an arbitrary and capricious manner in violation of 10 U.S.C. § 2377."

Time will tell how dramatically Palantir tilts the balance towards "commercial products" and "commercial services" (recently redefined in National Defense Authorization Act for Fiscal Year 2019, Pub. L. No. 115-232, § 836; 41 USCA § 103, 103a). It may amount to no more than a Pyrrhic victory for Palantir (as the Army appears to prefer a different solution), an increased paperwork burden for contracting officials, and an interesting footnote that interests loyal N\&CR readers. Nonetheless, it raises a number of interesting issues.

\section{Commercial Solutions To Complex Problems}

Among other things, Palantir reminds us that, just because a requirement is complex, complicated, critically important, or even extremely risky, it does not mean that the commercial marketplace cannot not offer a solution. While the National Aeronautics and Space Administration and the Air Force's ever-increasing reliance on commercial firms for space launch capacity aptly demonstrates that point, this case offers another instructive anecdote. Here, the court explained that the procuring agency's requirement was important, complicated, and complex:

The Distributed Common Ground System ("DCGS") is made up of Army, Air Force, Navy, and Marine Corps ground processing systems that can share information across the Joint Force. The overarching purpose of the [procurement was] to combine all of the Army's intelligence software/hardware capabilities into one program with the ability to access and be accessed by Army intelligence and command components, as well as other military and intelligence systems.

$$
* * *
$$

The performance work statement ("PWS")...stated that the requirements of DCGS-A2 included the "development of new data architecture, standards based enhanced visualization and analytical tools, cloud computing and 'big data' analytic capabilities; cyber analytics and data integration, visualization capabilities, Cyber Operations, Interoperability, Counter Intelligence/HUMINT, Weather, GEOINT, Geospatial Engineering and Sensor Management....

[T]he data management architecture "will serve as the architecture foundation and the heart with which the rest of the capabilities will depend on to function...." [Emphasis added.] 
Many of our students promptly, and at times viscerally, rejected the idea that such a critical, national defense-oriented requirement could be met with a commercial solution. The court explained, however, that, since 2009, Palantir had been marketing - to the both private sector and Government customers—its Gotham software product.

The software enables agencies to integrate, visualize, and analyze large amounts of data from different sources that reside in different databases in different formats. The parties stipulate that the government has previously procured the Palantir Gotham Platform on a commercial item basis, and that the GSA Schedule lists both term licenses and perpetual licenses for Palantir's platform....The parties also stipulate that Palantir Gotham is a commercially available data management platform. [Emphasis added.]

Palantir's appellate brief elaborated that "Gotham has been successfully deployed by the United States Marine Corps, United States Special Operations Command, FBI, and other agencies within the Department of Defense and Intelligence Community." The Army's subsequent, post-market research conclusion that "the [DCGS-A2] development effort cannot be procured as a commercial product" prompted this litigation.

\section{Protest Trends: Two Bites At The Apple, And Investing In Legal Talent}

Before delving more deeply into the court's reasoning, it's worth noting that Palantir joins the statistically insignificantbut seemingly expanding_-ranks of disappointed offerors that have not only sought, but enjoyed a more favorable result from, a second bite at the apple at the Court of Federal Claims after failing to obtain corrective action from the Government Accountability Office.

The GAO's rejection of Palantir's original preaward protest seemed unremarkable. In Palantir USG, Inc., Comp. Gen. Dec. B-412746, 2016 CPD II 138, the GAO began from the premise that "[a] contracting agency has the discretion to determine its needs and the best method to accommodate them." Accordingly, the GAO concluded that "the agency reasonably decided on its approach of having a single contractor, who would be responsible for selecting all the [system's] components..., and who would bear the responsibility for making certain that those components are integrated, in contrast to the phased approach favored by Palantir." Moreover, "the agency's approach is reasonably related to its need for a fully integrated and interoperable system made up of a number of specific capabilities, some of which are commercially available and some of which are not." Ultimately, the GAO found "no reason to question the approach chosen by the agency."

To the extent Palantir achieved the polar opposite result in the court and a subsequent affirmance at the Federal Circuit, one wonders whether some of the leading defense contractors will reconsider their empirically demonstrated unwillingness to bring bid protests at the Court of Federal Claims. See, e.g., our discussion of a December 2017 study, Bid Protests: The RAND Study of DOD Protests at the GAO and the COFC, 32 NCRNL II 10 ("the largest defense contractors (in terms of revenue) almost never bring their protests to the COFC. Protests from these firms were so rare that RAND concluded 'protests at COFC are not part of standard business practice for these firms.' ").

It an interesting twist, Palantir's Federal Circuit representation included some unusually high powered and well known appellate advocates: Theodore (Ted) B. Olson, former U.S. Solicitor General, and David Boies, who, among many other things, served as Special Trial Counsel to the Justice Department in the massive United States v. Microsoft litigation. That's particularly noteworthy to the extent that the RAND study appeared to endorse or validate investing in competent counsel when bringing a protest. Specifically, as we noted in 32 NCRNL II 10, RAND found that, "when small businesses are forced to use legal counsel, their protest sustained rates are similar to those of larger firms." At the time, we conceded our curiosity as to whether "the same data might be more critically analyzed with an eye towards correlating results with the qualifications and experience of protest counsel, rather than characteristics of the contractors themselves—but that was beyond the scope of the study." Palantir does nothing to dispel the notion that, in protest litigation, you get what you pay for.

\section{"Shall" Means, Well, Shall}

The most obvious takeaway from Palantir derives from one of the most basic tenets of statutory interpretation: when Congress uses the word "shall," rather than, for example, "may" or "should," its direction is mandatory (rather than discretionary). See, e.g., Federal Acquisition Regulation 2.101 (Shall means the imperative; and must is cross-referenced to shall. Conversely, may denotes the permissive; and should "means an expected course of action or policy that is to be followed unless inappropriate for a particular circumstance.") 
Under the Federal Acquisition Streamlining Act of 1994, 10 USCA $§ 2377$ (a), Congress articulated a preference for reliance on commercial items. Congress expressed that preference as a mandate, with a series of imperatives that, among other things, provides firms that offer commercial items an opportunity to compete by directing agencies to conduct market research, use (or rely upon) that market research, and acquire commercial items (to the maximum extent practical).

Specifically, 10 USCA $§ 2377$ (a) states: "The head of an agency shall ensure that, to the maximum extent practicable... requirements are defined so that commercial items... may be procured to fulfill such requirements; and...offerors of commercial items... are provided an opportunity to compete in any procurement to fill such requirements." (Emphasis added). In implementing this policy, Congress further specified in 10 USCA $\S 2377$ (b) that: "The head of an agency shall ensure that procurement officials in that agency, to the maximum extent practicable...acquire commercial items...to meet the needs of the agency...." (Emphasis added.) Remaining consistent in tone and usage, Congress also directed that: "The head of an agency shall conduct market research appropriate to the circumstances[,]" 10 USCA § 2377(c)(1) (emphasis added), after which:

(2) The head of an agency shall use the results of market research to determine whether there are commercial items...that-

(A) meet the agency's requirements;

(B) could be modified to meet the agency's requirements; or

(C) could meet the agency's requirements if those requirements were modified to a reasonable extent. [Emphasis added.]

For those keeping score at home, Congress deployed four consecutive usages of "shall" to signal its intent.

Against that backdrop, it's easy to understand why the Federal Circuit "conclud[ed] that the Army's procurement actions...were arbitrary and capricious and in violation of [10 USCA] § 2377," because, among other things, "the record shows that the Army did not use the results of [its] market research to determine whether there were commercial items that could meet its requirements, could be modified to meet its requirements, or could meet its requirements if those requirements were modified to a reasonable extent. See [10 USCA] $\S 2377$ (c)(2)." (Emphasis added.)

This simple, straightforward reading of this case—shall means shall (or, if Congress intended to give procurement officials greater discretion, Congress would have chosen different words (such as "may" or "should")—-seems entirely consistent with our prior observation that the Federal Circuit, historically, "prefers what some have described as a more consistent, streamlined, simplified, or even formalistic approach to its highly varied docket." See, e.g., Schooner, A Random Walk: The Federal Circuit's 2010 Government Contracts Decisions, 60 Am. U. L. Rev. 1067, 1095 (2011) (citing Thomas, Formalism at the Federal Circuit, 52 Am. U. L. Rev. 771, 773-74, 777 (2003) (arguing that "a formalist movement is afoot" in the Federal Circuit)).

\section{For the Record, The Record Matters}

All of which suggests that the most important lesson from Palantir might be that contracting agencies get no credit for conducting market research if they do not subsequently consider or rely upon that market research. But even that understates Palantir's message. The Federal Circuit appears to establish a relatively high bar for agencies to explain (on the record) why they rejected (or chose not to follow) market research indicating that a commercial solution might be available. In other words, when an agency's market research uncovers a single, potential commercial solution, the Federal Circuit considers disregarding that research—or failing to provide a sufficient explanation for why that potential solution is not in the Government's best interests—arbitrary and capricious behavior. Viewed solely through the lens of Administrative Procedure Act jurisprudence, that makes sense. As the court explained:

[T] he record must be sufficient to permit meaningful judicial review consistent with the Administrative Procedure Act, 5 U.S.C. $\S 706$. See Motor Vehicle Mfrs. Ass'n of U.S., Inc. v. State Farm Mut. Auto. Ins. Co., 463 U.S. 29, 43 (1983) (“[T]he agency must examine the relevant data and articulate a satisfactory explanation for its action including a 'rational connection between the facts found and the choice made.' ,' (quoting Burlington Truck Lines v. United States, 371 U.S. 156 (1962))); see also Sierra Club v. Gorsuch, 715 F.2d 653, 660-61 (D.C. Cir. 1983) ("If there is reasoned decision-making lurking behind such agency behavior, it is yet to be articulated. For agency action to be upheld, it must not only be explainable; it must also be explained.”)...

Here, the administrative record plainly shows that the Army was on notice that Palantir's product might be a commercial item that would satisfy its requirements, whether as-is or with modifications. Despite that notice, the Army's ultimate determination regarding its market research excluded commercial items from consideration in a conclusory fashion. [Emphasis added.] 
What's easy to miss is that the Army's most significant failure was not a failure to perform adequate market research. Indeed, "the administrative record demonstrates that the Army, while conducting its market research, was on notice of the desirability of hybrid options that used commercial solutions and that Palantir claimed to have a commercial item that could meet or be modified to meet the Army's needs." The Army erred when it appeared-at least on the record-to have ignored those findings or, at the very least, chose not to rely upon them. The court ruled for Palantir because "the Army did not use the results of that market research to determine whether there were commercial items that could meet its requirements, could be modified to meet its requirements, or could meet its requirements if those requirements were modified to a reasonable extent." Later, the court highlighted the inadequacy of information in the administrative record that justified the Army's decisionmaking:

[T] he Army was, or should have been, aware of Palantir's data management platform. Despite repeated notice that commercial products might well be available and could be modified to meet the Army's needs, the Army concluded that DCGS-A2 could not be procured as a commercial product with scant explanation.... There was no discussion in the Market Research Report to support the Army's conclusory assessment that these three requirements - data fusion, intelligence support, and DCGS integrated backbone-were not commercially available. Nor was there any discussion of whether any commercial items could have been modified to meet the Army's needs or the Army's requirements could have been modified so that commercial items could be used. [Emphasis added.]

Some procurement organizations may find that a bitter pill to swallow, while plenty of our readers will knowingly (if not smugly) nod their heads. The easiest way to lose a bid protest is to fail to document-in the contract file (and, thus, in the administrative record) - the rationale for significant agency decisions. This is not the first, nor will it be the last, time the Federal Circuit seeks to hold Government officials' feet to the fire in an effort to "impose more rigorous standards on the people in the government...that draft...government contracts." Nash, Jr., The Government Contracts Decisions of the Federal Circuit, 78 Geo. Wash. L. Rev. 586, 613-14 (2010).

\section{Market Research: Raising The Stakes}

Still, despite the passage of almost 25 years, Palantir comes as a surprise. Experienced procurement professionals are familiar with the broad range of statutory mandates and market research guidance found in the FAR. But we sense that conventional wisdom understood the market research rubric as more guidance than mandate. In other words, agencies enjoy broad discretion in conducting - and documenting - their market research. Nor did the court initially suggest otherwise, highlighting the absence of clear mandates with regard to documentation:

We acknowledge that there is no statutory or regulatory requirement for agencies to document their determinations pertaining to [10 USCA] § 2377 and FAR Part 10. See Advanced Am. Constr., Inc. v. United States, 111 Fed. Cl. 205, 227 (2013) ("[T] he language of [FAR] 10.002(e) is precatory in nature and does not establish any mandatory documentation requirement. That section states that agencies 'should' document the results of their market research; it does not state that those agencies 'shall' do so."). [Emphasis added.]

Moreover, recall that the Army engaged in extensive market research, including employing outside expert assistance. And, previously, when asked to interpret the same mandates from 10 USCA $\S 2377$, the GAO perceived that the Army had fulfilled its obligations, noting that "the agency conducted market research to inform its acquisition strategy. The market research included consideration of the availability of commercial items to meet the agency's needs." As a result, in 2016 CPD II 138, the GAO, unsurprisingly, had explained: “A protester's mere disagreement with the agency's judgment concerning the agency's needs and how to accommodate them does not show that the agency's judgment is unreasonable." (Emphasis added.)

Where the courts and the GAO appear to have diverged was in articulating the agency's duty to not just conduct market research, but to rely or act upon it in a specific way. The GAO acknowledged that FAR 12.101 "directs agencies to, among other things, conduct market research to determine whether commercial items...are available that could meet the agency's requirements [and]...requires agencies to acquire commercial items... when they are available to meet the needs of the agency." Yet the GAO granted the Army a healthy dollop of deference in determining what to do with its market research. The GAO simply reiterated the unremarkable proposition that:

Determining whether a product or service is a commercial item is largely within the discretion of the contracting agency, and such a determination will not be disturbed by our Office unless it is shown to be unreasonable. Aalco Forwarding, Inc., et al., B-277241.8, B-277241.9, Oct. 21, 1997, 97-2 CPD II 110 at 11.

Aalco Forwarding, Inc., Comp. Gen. Dec. B-277241.8, 97-2 CPD II 110, 1997 WL 649182, followed, in turn, two protests 
of whether an awardee's product was a commercial item, Canberra Industries, Inc., Comp. Gen. Dec. B-271016, 96-1 CPD II 269, 1996 WL 302696, and Coherent, Inc., Comp. Gen. Dec. B-270998, 96-1 CPD II 214, 1996 WL 229116. See also, for the same proposition, Coulson Aviation (USA), Inc., Comp. Gen. Dec. B-414566, 2017 CPD II 242, 2017 WL 3530385 (citing Palantir, 2016 CPD II 138, and concluding that the "protester was not prejudiced by the agency's failure to conduct the procurement using commercial item acquisition procedures because it does not currently offer a commercial item meeting the agency's requirements"); Crescent Helicopters, Comp. Gen. Dec. B-284734, 2000 CPD II 90, 2000 WL 706977 (agency reasonably concluded, based upon its market research, that the helicopter services were offered and sold competitively in substantial quantities to corporations); CW Government Travel, Inc., Comp. Gen. Dec. B-283408, 99-2 CPD II 89, 1999 WL 1049624 ("a significant portion of travel service providers in the marketplace continue to rely on [this] type of commissionbased funding”); and Premier Engineering \& Manufacturing, Inc., Comp. Gen. Dec. B-283028, 99-2 CPD II 65, 1999 WL 828067 (agency reasonably determined that the offered de-icer satisfied the solicitation's commerciality requirements).

In deferring to the procuring agency, the GAO chose not to parse the language of FAR 10.002(d)(1):

If market research establishes that the Government's need may be met by a type of item or service customarily available in the commercial marketplace that would meet the definition of a commercial item at [FAR] Subpart 2.1, the contracting officer shall solicit and award any resultant contract using the policies and procedures in [FAR] Part 12. [Emphasis added.]

The Federal Circuit began from the same starting place as the GAO, giving "deference to the Army's procurement decisions. Advanced Data Concepts, Inc. v. U.S., 216 F.3d 1054, 1058 (Fed. Cir. 2000).” Then, diverging from the GAO, the court promptly seized upon the word "shall" and saw nothing inherent in the nature of market research to suggest Congress intended that agencies enjoy discretion once market research indicated that "the Government's need may be met by a type of item or service customarily available in the commercial marketplace that would meet the definition of a commercial item at Subpart 2.1." (Emphasis added.)

As noted above, that's a simple, almost elegant result, even if, in 2018 - again, nearly 25 years after Congress passed FASA - we find it jarring. Maybe it doesn't sit well because, in effect, it mandates that the procuring agency use Part 12 commercial item procedures despite the (very real) possibility that the Government's needs might not be met by a solution from the commercial marketplace. In other words, the standard for mandating use of Part 12 commercial item procedures seems inordinately, arguably inappropriately, low.

For example, contrast this mandate with the FAR guidance for setting aside procurements above the simplified acquisition threshold, found in FAR 19.502-2(b):

The contracting officer shall set aside any acquisition over [the simplified acquisition threshold] for small business participation when there is a reasonable expectation that-

(1) Offers will be obtained from at least two responsible small business concerns offering the products of different small business concerns...; and

(2) Award will be made at fair market prices. Total small business set-asides shall not be made unless such a reasonable expectation exists....

Use of the word "may," in FAR 10.002(d)(1), with regard to the potential availability of a commercial item establishes a lower bar than the requirement of "a reasonable expectation" that "at least two responsible small business concerns" will submit offers.

Nor does FAR Part 10 require that the commercial solution (that, again, may or may not be available) can be obtained at a fair market price. We might intuit that the commercial item definition implies availability at a fair market price, but that's currently only the case for one of the eight flavors of commercial items in the FAR 2.101 definition: "Services of a type offered and sold competitively in substantial quantities in the commercial marketplace based on established catalog or market prices for specific tasks performed or specific outcomes to be achieved and under standard commercial terms and conditions." And, of course, even that definition includes catalog prices as a surrogate for, or alternative to, market prices. We have plowed this ground before. See, e.g., Postscript IV: Defining Commercial Services, 14 N\&CR II 39, where we noted that a key difficulty in determining the meaning of the commercial item definition was the lack of agreement on the meaning of "established market 
price." See also Postscript: Defining Commercial Services, 11 N\&CR II 34, where we argued that an established market price could be one that was established by obtaining competitive prices for a specific task at the time commercial item was bought. It is unclear how well Palantir fits the rule that Ralph suggested there, that: "A service is commercial if it is sold regularly in the commercial marketplace at prices that can be used to ensure that prices offered to the Government are fair and reasonable."

\section{Commercial Contractors: Blow Your Own Horn}

Contractors take note: while it's easy to fault the Army's contracting organization for failure to document the contracting file (and, thus, the administrative record), credit is also due to Palantir for teaching an important lesson. Contractors that believe they can provide a commercial product that meets the Government's needs should explicitly inform the Government of their capabilities, early in the process, and frequently remind the Government what they bring to the table. Moreover, contractors should memorialize or document those exchanges and ensure that the critical information makes its way into the agency's contracting files. See, generally, FAR 4.803(a)(1), 10.002(d) \& (e). Palantir communicated its abilities early and often through various means. Palantir repeatedly responded to the Army's Requests for Information, highlighted its other contracts, raised concerns with the Army's acquisition approach, responded to the Army's draft performance work statement, filed a pre-award protest with the GAO, and, of course, proceeded directly from the GAO to the COFC. Palantir's marketing efforts-and their repeated, detailed exchanges with the Government—factored heavily in the court's analysis.

\section{A Less Optimistic Spin?}

On their firm's blog, Nathaniel Catellano (a former Federal Circuit clerk and thoughtful court observer) and his colleagues suggested that Palantir has the potential to generate more protests, as "commercial vendors may be more willing to object to agency decisions to utilize FAR Part 15 procedures, or even specific solicitation provisions that are not consistent with commercial practice...." See Castellano, Blanchard, and Casimir, Palantir: Federal Circuit Confirms Agencies' Obligations To Prioritize Commercial Solutions, Arnold \& Porter Perspectives (Sept. 17, 2018), https://www.arnoldporter.com/en/perspectiv es/publications/2018/09/palantir-federal-circuit-confirms-agencies. They also warn of a potential backlash that could threaten the preference for commercial product or commercial services procurement.

[T]here will likely be more pre-award protests challenging solicitations on the basis that an agency has not satisfied its obligations under FASA. While sufficient documentation of market research and the reasoning behind any given solicitation provision or acquisition strategy may suffice to ultimately defeat a protest, such evidence may not protect the agency from having to defend itself in protest proceedings....In a market where many different companies are vying to influence the terms of a solicitation, such litigation could grow complex and unwieldy.... These potential complications could ultimately limit the effectiveness of commercial item contacting. If the requirements associated with commercial item contracting (supposedly simplified compared to noncommercial contracting) become too onerous, that may fuel recent trends of moving acquisition to non-procurement channels, particularly Other Transactions, for which oversight and judicial review are less readily available.

We agree that Palantir sends a clear message to Government officials that they need to more carefully document their market research and post-market research decisionmaking. Nonetheless, we think it's premature to worry about Congress rolling back the commercial purchasing preference.

\section{Postscript: Single Award IDIQ’s And Essay Writing}

The Army's decision to exclude Palantir's Gotham platform—rather than consider it as a partial solution—derived from the Army's pursuit of "a single contractor to be the system data architect, developer, and integrator." That raised eyebrows, because the Army's Market Research Report, which concluded that use of a commercial product was not an option, failed to reconcile or explain away a prior report, prepared by the Army Materiel Systems Analysis Activity, which "concluded that a hybrid COTS-development approach was the best of the three alternatives, noting that such an approach was currently functioning in the Department of Defense Intelligence Community and would only require minor development to fill capability gaps."

Nonetheless, a few months later, the Senior Procurement Executive signed a Determination and Findings for "Award of a Single Source Indefinite-Delivery Indefinite-Quantity (IDIQ) Single Award Contract...[concluding, among other things, that 
a] single-source task or delivery order contract...[wa]s authorized because the task or delivery orders expected under the contract are so integrally related that only a single source can reasonably perform the work." That song sounds familiar. See, e.g., Indefinite-Delivery/Indefinite-Quantity Contracts: Time To Correlate Practice and Policy?, 32 NCRNL II 44 (“[D]espite FAR 16.500(a)'s established preference for multiple awards, '[o]f the DOD awards for the indefinite-delivery /indefinitequantity (IDIQ) contract type during this period, about three-quarters were made to a single contractor, rather than multiple contractors.'",).

The analogy suggests that Palantir's legacy may be that another congressional preference has generated another acquisition planning drafting exercise - the need for better (time will tell how much better) agency documentation of post-market research determinations regarding the availability (or unavailability) of commercial solutions necessary to satisfy 10 USCA $\S 2377$ and FAR Part 10 - before agencies choose an alternative acquisition strategy. Is it worth the candle? SLS 